\title{
Advances in research of TGF-B1 in human testis
}

\author{
Tingting WANG ${ }^{1}$, Dan ZHANG², Tao SONG ${ }^{1}$, Mengdi SUN ${ }^{1}$, Jidong ZHANG ${ }^{3 *}$ (D)
}

\begin{abstract}
Transforming growth factor $\beta 1$ (TGF- $\beta 1$ ) is a polypeptide growth factor with various biological activities. Recent studies have shown that this growth factor and they receptors are expressed in human Leydig cells, Sertoli cells, spermatogonia, spermatocytes and sperm cells after birth, and are involved in the endocrine regulation of spermatogenesis. However, there is no report on the expression of TGF- $\beta$ in human embryonic testis. TGF- $\beta 1$ is a peptide growth factor widely distributed in germ cells at various levels in the testis, regulating the function of the testes and maintaining the stability of the testis environment by acting on various cells. This review summarizes the research progress of TGF- $\beta 1$ in human testis.
\end{abstract}

Keywords: transforming growth factor $\beta 1$; TGF- $\beta 1$; testicular genesis; biological functions; polypeptide growth.

Practical Application: There is currently no effective treatment to prevent or reverse the progression of testicular reproductive diseases.

\section{Introduction}

Testicular formation and spermatogenesis is a delicate and complex process. There are complex cellular pathways between various cells, and the secretion and action of various hormones are complicated. In the four classical signaling pathways regulating growth and development of Wnt, TGF- $\beta$, Notch, and Hedgehog, normal testicular development and spermatogenesis are closely related to TGF $\beta$ signaling pathway.

In newborn fetal testes, several ligands including Nodal, TGF- $\beta$, Activins and BMP play a key role in regulating male pluripotency, somatic and germline proliferation, testicular angiogenesis and structure. In postnatal life, in addition to the specified germline differentiation and proliferation, local production of these factors determines adult testicular size by regulating cell proliferation and differentiation. Because TGF- $\beta$ superfamily signaling is indispensable for testicular formation, it can lead to testicular disease and can lead to reduced fertility in men (Young et al., 2015; Kwiatkowski et al., 2014).

TGF- $\beta /$ Smad signaling pathway and HF TGF- $\beta$ receptor $(T \beta R)$ is a cell membrane surface receptor, which can be divided into three types according to the structure and characteristics of the receptor, which are TGF- $\beta$ type I receptor (T $\beta$ RI), TGF- $\beta$ type II receptor (T $\beta$ RII), TGF- $\beta$ type III receptor (T $\beta$ RIII). Among them, T $\beta R I$ and T $\beta R I I$ have Ser/Thr protein kinase activity necessary for cell signal transduction due to their transmembrane region containing a serine (Ser)/threonine (Thr) protein kinase domain. The T $\beta R I$ proximal membrane region has a serine-rich (Ger)/glycine (Gly)-rich domain, called the GS domain, which is the region of receptor kinase activity and is activated by T $\beta$ RII phosphorylation. TGF- $\beta$ is first T $\beta$ RII binding undergoes non-ligand-dependent autophosphorylation activation to form a complex, at which point T $\beta$ RII phosphorylation kinase is activated, T $\beta R I$ recognizes and binds to this compound, and is activated by phosphorylation of T $\beta$ RII phosphorylation kinase, through such a process Initiation of intracellular signal generation.

It is generally believed that in TGF- $\beta$-induced signal transduction, TGF- $\beta$ first directly binds to T $\beta$ RII to form a complex, TGF- $\beta$ conformation changes, is recognized by T $\beta$ R- 1 and binds to form T $\beta$ RII-TGF- $\beta$-T $\beta$ RI trimer complex, T $\beta$ RI in the complex is phosphorylated by T $\beta$ RII, causing its substrate to amplify the signal and further downstream, which is the most important way of binding the receptor to the ligand, that is the mediated recruitment method (Nayeem \& Deep 2014). Among them, auto-phosphorylation of T $\beta$ RII is essential, and Ser/Thr phosphorylation of T $\beta \mathrm{R} 1 \mathrm{GS}$ region is a necessary pathway to mediate TGF $\beta$ signaling, and its specificity of kinase determines downstream signal specificity. Therefore, TGF- $\beta$ signaling is dependent on the interaction and presence of T $\beta R I$ and T $\beta$ RII. Another way is synergistic: T $\beta R I$ and T $\beta R I I$ interact with the ligand in a synergistic manner, without prioritization. When these two receptors are simultaneously expressed in the cell and present on the cell membrane, their affinity with the ligand is greatly enhanced (Sabbineni et al. 2018).

\section{The effect of TGF- $\beta 1$ on Sertoli cells}

The mammalian testis is divided into two compartments, $\square$ tubular compartment and Leydig cell compartment: tubules composed of Sertoli cells, peritubular myoid cells and various generations of germ cells (spermatogonial stem cells, meiotic spermatocytes, 
and spermatozoa); and interstitial space (between seminiferous tubules) consisting of blood vessels, tissue-resident immune cells, and testosterone-producing Leydig cells (Cheng \& Mruk 2012). These Sertoli cells form the blood testis barrier (BTB), also known as the Sertoli cell barrier, which functions to protect developing germ cells from systemic attack by adaptive immune cells while providing nutrient and structural support (Wen et al., 2016; Luca et al., 2018). It is well known that tight junctions formed by adjacent Sertoli cells are a major component of the blood testis barrier and it plays an important role in maintaining the microenvironment of spermatogenesis in the testes. The testis is the main male reproductive organ (spermogenesis) and synthetic androgen, which produces sperm, mainly testosterone (Li et al., 2018; Zhu et al., 2019). Due to the presence of BTB, immune cells and factors are usually not delivered from the blood to the lumen of the seminiferous tubules, the main component of which is tight junction, the formation of adjacent Sertoli cells 10. Various members of Occludin (Ocln), claudin (Cldn) and Zonula Occludens-1 (ZO-1), as major TJs-associated proteins, are thought to be directly involved in this barrier mechanism, they play an important role in maintaining testicular homeostasis. Therefore, Sertoli cells have been described as key cells for spermatogenesis (Wu et al., 2017; Wen et al., 2018).

Testicular Sertoli cells are target cells for the action of TGF- $\beta 1$ (Wang et al., 2013). Rao et al. (2019) found that TGF- $\beta 1$ regulates the secretion of immature testicular cells in a time- and dose-dependent manner, suggesting that TGF- $\beta 1$ may be involved in normal spermatogenic epithelial development. FSH-treated Sertoli cells are functionally dose-dependently increased, and the addition of TGF- $\beta 1$ reduces the action of this gonadotropin, which is dose-dependent. TGF- $\beta 1$ significantly reduced FSH-induced cAMP levels in cultured Sertoli cells, which attenuated the effect of FSH on Sertoli cell physiology by indirectly acting by reducing cAMP levels (Rindone et al., 2018). FSH-induced cAMP is a local product that may function through the secretion function of testicular cells (Jockusch et al., 2014). Sertoli cell transcription factors regulate testicular integrity including the WT1-SOX8 / SOX9-beta-CAT-ENIN-DHH network, GPR56, STIM1 and NR0B1 (also known as DAX1).

We believe that the mechanism of TGF regulation in Sertoli cells is much more complicated than originally thought (Hu et al., 2018). Expression of Lertig-tagged TGF- $\beta 1$ in Sertoli cells in residual intact testicular cells suggests that transdifferentiation of Sertoli cells to Leydig-like cells is unlikely to be a driving factor of testis. Further research is needed to determine the cause and underlying mechanisms, while emphasizing the underestimated effects of peritubular myoid cells in testicular maintenance and their cooperation with Sertoli cells (Oral et al., 2008).

Through Sertoli cell proliferation (e.g., SMAD4, GATA4, and TGF- $\beta 1$ signaling), Leydig cell products (e.g., ACTIVINA vascular development) regulate testicular size, shape and number and available gonad space (e.g. observed in the Ift144 mutant mouse). Further research requires a genetic model to reveal the underlying mechanisms of gene network and sex determination to regulate the integrity and morphology of testicle lobule (Chen \& Liu 2015; Sheng et al., 2017).

\section{Effect of TGF- $\beta 1$ on peritubular myoid cells}

Peritubular myoid cells localize to the luminal side of endothelial cells and the luminal side of adventitial fibroblasts, covering small blood vessels and large blood vessels (Chen \& Liu 2016), forming the structural framework of seminiferous tubules, contribute to the basal lamina, and are a vital part of testis paracrine signaling network. Ultrastructural studies have shown that peritubular myoid cells $\square$ lack dense bodies and less myofilament. TGF- $\beta 1$ is mainly mediated by type 1 receptors, which promotes the proliferation of extracellular matrix, activates cells' PAL-1, and coordinates with PAL- 1 secreted by the Sertoli cells (Zhang et al., 2014). Experimental analysis of cell proliferation and DNA synthesis of $\mathrm{H}$-deoxythymidine found that TGF- $\beta 1$ could not affect the proliferation of peritubular myoid cells and Sertoli cells, but inhibited the synthesis of DNA from peritubular myoid cells induced by TGFa. In addition, the product of TGF- $\beta 1$ acting on the peritubular myoid protein is mainly composed of collagen, fibronectin and proteoglycan, which are components of the basement membrane, suggesting that the regulation of the seminiferous tubules and the Sertoli cells on the basal layer of the seminiferous tubule is likely to be achieved by TGF- $\beta$ (Anderson et al., 2008). The expression of TGF- $\beta 1$ in the testis is closely related to its biological function, regulating the ability of the testis by maintaining the function of various cells, maintaining the testis-inner environment-stability.

\section{Effect of TGF- $\beta 1$ on Leydig cells}

TGF- $\beta 1$ is widely present in the spermatogenic cells of the testis, which regulates testicular function by regulating various cells including Leydig cells and Sertoli cells, thereby maintaining the stability of the testis environment. It plays an important role in the process of spermatogenesis. TGF- $\beta 1$ is expressed in different cells of the testis at different developmental stages: In the neonatal period, TGF- $\beta 1$ is mainly expressed in spermatogonia and Leydig cells, but is expressed in Sertoli cells before puberty, and is mainly expressed in various sperm cells in maturity.

The high expression of TGF- $\beta 1$ in the testis can affect the normal spermatogenic function of the body (Yao et al., 2015). Because Leydig cells are the main site for the conversion of androgen into estrogen, and in male sexual maturity, TGF- $\beta 1$ is mainly expressed in Leydig cells, while they are mainly found in the testicular stroma. Due to the presence of the testicular specific structure of the blood testis barrier, it is difficult for drugs to pass the blood testis barrier. When TGF- $\beta 1$ receptor I blocker was injected into the testicular stroma of model rats by microinjection, it effectively blocked the expression of TGF- $\beta 1$ in Leydig cells and can avoid the effect of the blood testis barrier on the effect of blockers (Oral et al. 2008). Blockers can significantly increase rat sperm density and sperm motility as well as fast forward $\square$ movement (Grade A) and slow forward movement (Grade B). Furthermore, it was observed under high power microscope that it decreased the expression of TGF- $\beta 1$ in the testis of the model rats, and the expression of CYP19 was increased and sperm production was increased. T $\beta R I$ can improve sperm quality and increase serum sex hormone levels (Nagaoka \& Saitou 2017). 


\section{The effect of TGF- $\beta 1$ on spermatogonia}

TGF- $\beta 1$ expression was observed in normal Leydig cells, sperm cells and Sertoli cells. The testicular stroma mainly includes Leydig cells, dendritic cells, macrophages, and other immune cells (Johnson et al., 2008). Morphological analysis showed that TGF- $\beta 1$ was mainly expressed in Leydig cells (Hu et al., 2018), suggesting that Leydig cells can participate in the regulation of testicular immune microenvironment and normal spermatogenesis by secreting TGF- $\beta 1$. TGF- $\beta 1$ is expressed in the posterior acrosome, the neck and the middle of the tail (Combes et al., 2009). The expression of TGF- $\beta 1$ in testicular spermatogenic epithelial cells indicates that the sperm has TGF- $\beta 1$ expression before entering the epididymis. TGF- $\beta 1$ expression can be seen in the tight junctions between Sertoli cells, suggesting that TGF- $\beta 1$ may play an important role in maintaining the structural stability of the fine tubules. It was found that the expression of TGF- $\beta 1$ was found in the nucleus and cytoplasm of seminoma cells, and the expression level was significantly higher than that in normal testes (Stukenborg et al., 2009).

The position where $\mathrm{N}$-cadherin is mainly expressed is the tight junction between the Sertoliacells adjacent to the base of the normal testis, suggesting that it plays an important role in maintaining the structural stability of the seminiferous tubules and the migration of spermatogenic cells from the basal to the lumen (Anderson et al., 2008).

\section{Problems and prospects}

TGF $\beta$ is a post-transcriptional regulatory molecule essential for gene expression in physiological and pathological processes. Inflammation, apoptosis, proliferation, differentiation, signal transduction, wound healing, fibrosis, and tissue development, differentiation, and repair are all regulated by TGF- $\beta 1$ (Wen et al. 2016). There is increasing evidence that TGF- $\beta 1$ is closely related to the development of many human diseases, and that different stages of the same disease are associated with different TGF- $\beta 1$ expression profiles (Endo et al., 2017). In recent years, it has been shown to be associated with a variety of testicular formation and maintenance abnormalities associated with various diseases, including infertility, sexual developmental disorders and testicular hypoplasia syndrome susceptibility to TGF- $\beta 1$ network regulation (Wharton \& Derynck 2009). Therefore, elucidation of the regulatory role and mechanism of TGF cell signaling may contribute to the diagnosis, progression, severity judgment and prognosis assessment of infertility, and may make it a potential therapeutic target.

There is currently no effective treatment to prevent or reverse the progression of testicular reproductive diseases. Increasing awareness of the molecular mechanisms of TGF $\beta$ will also help to discover new strategies for the treatment of reproductive diseases. For example, biomarkers identified as specific miRNAs for male reproductive diseases can provide new insights into the phased, specific, and targeted therapies of reproductive diseases.

Questions worthy of consideration or need to be clarified include 1. Is the mechanism of action of TG-F $\beta 1$ and most signaling pathways in systemic male reproductive diseases mediated by different signaling pathways? 2. Do many signaling pathways have TGF- $\beta 1$ interference? 3. Is there more new TGF- $\beta 1$ involved in the regulation of these signaling pathways or more related signaling pathways? 4 . How is TGF- $\beta 1$ associated with male reproductive physiology?

\section{Acknowledgments}

This work was supported by the National Nature Science Foundation of China (NSFC.31660338, 31960156); High School Science and Technology Talent Support Project of Guizhou Province (QJH-KY-2016-079); Natural Science Foundation of Guizhou Province (QKH-2016-1167); The Scientific and Technological Innovation Project for Oversea Students of Guizhou province (QR-2016-20), Natural Science Foundation of Guizhou Province (QKHZ-2019-2829).

\section{References}

Sabbineni, H., Verma, A., \& Somanath, P. R. (2018). Isoform-specific effects of transforming growth factor $\beta$ on endothelial-to-mesenchymal transition. Journal of Cellular Physiology, 233(11), 8418-8428. http:// dx.doi.org/10.1002/jcp.26801. PMid:29856065.

Anderson, E. L., Baltus, A. E., Roepers-Gajadien, H. L., Hassold, T. J., de Rooij, D. G., van Pelt, A. M., \& Page, D. C. (2008). Stra8 and its inducer, retinoic acid, regulate meiotic initiation in both spermatogenesis and oogenesis in mice. Proceedings of the National Academy of Sciences of the United States of America, 105(39), 1497614980. http://dx.doi.org/10.1073/pnas.0807297105. PMid:18799751.

Chen, S. R., \& Liu, Y. X. (2015). Regulation of spermatogonial stem cell self-renewal and spermatocyte meiosis by Sertoli cell signaling. Reproduction (Cambridge, England), 149(4), R159-R167. http:// dx.doi.org/10.1530/REP-14-0481. PMid:25504872.

Chen, S. R., \& Liu, Y. X. (2016). Testis cord maintenance in mouse embryos: Genes and signaling. Biology of Reproduction, 94(2), 42. http://dx.doi.org/10.1095/biolreprod.115.137117. PMid:26792939.

Cheng, C. Y., \& Mruk, D. D. (2012). The blood-testis barrier and its implications for male contraception. Pharmacological Reviews, 64(1), 16-64. http://dx.doi.org/10.1124/pr.110.002790. PMid:22039149.

Combes, A. N., Wilhelm, D., Davidson, T., Dejana, E., Harley, V., Sinclair, A., \& Koopman, P. (2009). Endothelial cell migration directs testis cord formation. Developmental Biology, 326(1), 112-120. http:// dx.doi.org/10.1016/j.ydbio.2008.10.040. PMid:19041858.

Endo, T., Freinkman, E., de Rooij, D. G., \& Page, D. C. (2017). Periodic production of retinoic acid by meiotic and somatic cells coordinates four transitions in mouse spermatogenesis. Proceedings of the National Academy of Sciences of the United States of America, 114(47), E10132-E10141. http://dx.doi.org/10.1073/pnas.1710837114. PMid:29109271.

Hu, S. G., Liang, A. J., Yao, G. X., Li, X. Q., Zou, M., Liu, J. W., \& Sun, Y. (2018). The dynamic metabolomic changes throughout mouse epididymal lumen fluid potentially contribute to sperm maturation. Andrology, 6(1), 247-255. http://dx.doi.org/10.1111/andr.12434. PMid:29194995.

Jockusch, H., Holland, A., Staunton, L., Schmitt-John, T., Heimann, P., Dowling, P., \& Ohlendieck, K. (2014). Pathoproteomics of testicular tissue deficient in the GARP component VPS54: The wobbler mouse model of globozoospermia. Proteomics, 14(7-8), 839-852. http:// dx.doi.org/10.1002/pmic.201300189. PMid:24115398.

Johnson, L., Thompson, D. L. Jr, \& Varner, D. D. (2008). Role of Sertoli cell number and function on regulation of spermatogenesis. Animal 
Reproduction Science, 105(1-2), 23-51. http://dx.doi.org/10.1016/j. anireprosci.2007.11.029. PMid:18242891.

Kwiatkowski, W., Gray, P. C., \& Choe, S. (2014). Engineering TGF- $\beta$ superfamily ligands for clinical applications. Trends in Pharmacological Sciences, 35(12), 648-657. http://dx.doi.org/10.1016/j.tips.2014.10.006. PMid:25458539.

Li, X. Y., Zhang, Y., Wang, X. X., Jin, C., Wang, Y. Q., Sun, T. C., Li, J., Tang, J. X., Batool, A., Deng, S. L., Chen, S. R., Cheng, C. Y., \& Liu, Y. X. (2018). Regulation of blood-testis barrier assembly in vivo by germ cells. The FASEB Journal, 32(3), 1653-1664. http://dx.doi. org/10.1096/fj.201700681R. PMid:29183964.

Luca, G., Baroni, T., Arato, I., Hansen, B. C., Cameron, D. F., \& Calafiore, R. (2018). Role of Sertoli Cell Proteins in Immunomodulation. Protein and Peptide Letters, 25(5), 440-445. http://dx.doi.org/10.21 74/0929866525666180412163151. PMid:29651939.

Nagaoka, S. I., \& Saitou, M. (2017). Reconstitution of female germ cell fate determination and meiotic initiation in mammals. Cold Spring Harbor Symposia on Quantitative Biology, 82, 213-222. http://dx.doi. org/10.1101/sqb.2017.82.033803. PMid:29208639.

Nayeem, S. M., \& Deep, S. (2014). pH modulates the TGF- $\beta$ ligands binding to the receptors: a computational analysis. Journal of molecular recognition. JMR, 27(8), 471-481. http://dx.doi.org/10.1002/ jmr.2368. PMid:24984864.

Oral, O., Uchida, I., Eto, K., Nakayama, Y., Nishimura, O., Hirao, Y., Ueda, J., Tarui, H., Agata, K., \& Abé, S. (2008). Promotion of spermatogonial proliferation by neuregulin 1 in newt (Cynops pyrrhogaster) testis. Mechanisms of Development, 125(9-10), 906917. http://dx.doi.org/10.1016/j.mod.2008.06.004. PMid:18586089.

Rao, M., Ke, D., Cheng, G., Hu, S., Wu, Y., Wang, Y., Zhou, F., Liu, H., Zhu, C., \& Xia, W. (2019). The regulation of CIRBP by transforming growth factor beta during heat shock-induced testicular injury. Andrology, 7(2), 244-250. http://dx.doi.org/10.1111/andr.12566. PMid:30461215.

Rindone, G. M., Gorga, A., Regueira, M., Pellizzari, E. H., Cigorraga, S. B., Galardo, M. N., Meroni, S. B., \& Riera, M. F. (2018). Metformin counteracts the effects of FSH on rat Sertoli cell proliferation. Reproduction (Cambridge, England), 156(2), 93-101. http://dx.doi. org/10.1530/REP-18-0233. PMid:29789441.

Sheng, Z. Y., Gao, N., Wang, Z. Y., Cui, X. Y., Zhou, D. S., Fan, D. Y., Chen, H., Wang, P. G., \& An, J. (2017). Sertoli Cells Are Susceptible to ZIKV Infection in Mouse Testis. Frontiers in Cellular and Infection Microbiology, 7, 272. http://dx.doi.org/10.3389/fcimb.2017.00272. PMid:28680856.

Stukenborg, J. B., Schlatt, S., Simoni, M., Yeung, C. H., Elhija, M. A., Luetjens, C. M., Huleihel, M., \& Wistuba, J. (2009). New horizons for in vitro spermatogenesis? An update on novel three-dimensional culture systems as tools for meiotic and post-meiotic differentiation of testicular germ cells. Molecular Human Reproduction, 15(9), 521529. http://dx.doi.org/10.1093/molehr/gap052. PMid:19561342.

Wang, X. X., Ying, P., Diao, F., Wang, Q., Ye, D., Jiang, C., Shen, N., Xu, N., Chen, W. B., Lai, S. S., Jiang, S., Miao, X. L., Feng, J., Tao, W. W., Zhao, N. W., Yao, B., Xu, Z. P., Sun, H. X., Li, J. M., Sha, J. H., Huang, X. X., Shi, Q. H., Tang, H., Gao, X., \& Li, C. J. (2013). Altered protein prenylation in Sertoli cells is associated with adult infertility resulting from childhood mumps infection. The Journal of Experimental Medicine, 210(8), 1559-1574. http://dx.doi.org/10.1084/ jem.20121806. PMid:23825187.

Wen, Q., Li, N., Xiao, X., Lui, W. Y., Chu, D. S., Wong, C., Lian, Q., Ge, R., Lee, W. M., Silvestrini, B., \& Cheng, C. Y. (2018). Actin nucleator Spire 1 is a regulator of ectoplasmic specialization in the testis. Cell Death \& Disease, 9(2), 208. http://dx.doi.org/10.1038/s41419-0170201-6. PMid:29434191.

Wen, Q., Wang, Y., Tang, J., Cheng, C. Y., \& Liu, Y. X. (2016). Sertoli Cell Wt1 regulates peritubular myoid cell and fetal leydig cell differentiation during fetal testis development. PLoS One, 11(12), e0167920. http:// dx.doi.org/10.1371/journal.pone.0167920. PMid:28036337.

Wharton, K., \& Derynck, R. (2009). TGFbeta family signaling: novel insights in development and disease. Development (Cambridge, England), 136(22), 3691-3697. http://dx.doi.org/10.1242/dev.040584. PMid:19855012.

Wu, D., Huang, C. J., Khan, F. A., Jiao, X. F., Liu, X. M., Pandupuspitasari, N. S., Brohi, R. D., \& Huo, L. J. (2017). SENP3 grants tight junction integrity and cytoskeleton architecture in mouse Sertoli cells. Oncotarget, 8(35), 58430-58442. http://dx.doi.org/10.18632/ oncotarget.16915. PMid:28938568.

Yao, H. C., Ungewitter, E., Franco, H., \& Capel, B. (2015). Establishment of fetal Sertoli cells and their role in testis morphogenesis. Sertoli Cell Biology, 2015, 57-79. http://dx.doi.org/10.1016/B978-0-12417047-6.00002-8.

Young, J. C., Wakitani, S., \& Loveland, K. L. (2015). TGF- $\beta$ superfamily signaling in testis formation and early male germline development. Seminars in Cell \& Developmental Biology, 45, 94-103. http://dx.doi. org/10.1016/j.semcdb.2015.10.029. PMid:26500180.

Zhang, J., Hatakeyama, J., Eto, K., \& Abe, S. (2014). Reconstruction of a seminiferous tubule-like structure in a 3 dimensional culture system of re-aggregated mouse neonatal testicular cells within a collagen matrix. General and Comparative Endocrinology, 205, 121132. http://dx.doi.org/10.1016/j.ygcen.2014.03.030. PMid:24717811.

Zhu, R., Wang, J., Feng, T., Hu, X., Jiang, C., Wang, X., Li, K., Sang, Y., Hua, Y., Sun, H., Yao, B., \& Li, C. (2019). The alteration of RhoA geranylgeranylation and Ras farnesylation breaks the integrity of the blood-testis barrier and results in hypospermatogenesis. Cell Death \& Disease, 10(6), 450. http://dx.doi.org/10.1038/s41419-0191688-9. PMid:31171774. 